SAL $27 / 2015$

Equivalence and Variants Causing Dichotomy in Translating the Terminology of Economics

Received 03/2015 Accepted 09/2015
Equivalence and Variants Causing Dichotomy in Translating the Terminology of Economics

\section{Ekvivalentiškumo siekis verčiant terminų variantais - dichotomijos priežastis}

\title{
Viorika Šestakova
}

Lecturer in EAP and ESP at Kaunas University of Technology, Faculty of Social Sciences, Arts and Humanities, Lithuania.

$\Gamma$ crossef http://dx.doi.org/10.5755/j01.sal.0.27.13741

\section{Abstract}

Some of special lexicon is supplemented with two or three designations that can imply professional or local usage, and thus generally can influence the emergence of some variants in the source language as well as in the target language. Whereas in translation as a semiotic practice the meaning that remains unchanged when a particular transformation is applied to it, is considered as an invariant. The translation of the special lexicon regarding the variants can signify dichotomy of form and meaning, tending to depart from the main point or cover a difference in meaning in the target language. Also, seeking for the equivalence of the lexical units in translation, therefore, the variants can cause ambiguity of the phenomenon when discussing the meaning in translation that can be understood as a chain of interpretations.

The investigation suggests the descriptive-comparative study of the special lexicon of economics in regard to the equivalence in translation concerning expression and meaning between the source language and the target language.

KEYWORDS: translation as a semiotic practice, special lexicon, dichotomy, (in)variant, equivalence, terms.

\section{Introduction}

Scientific and technological investigations of different phenomena cannot do without creating appropriate linguistic and semiotic expressions relevant to the entities being known or perceived philosophically, or inferred to have their own distinct existence, relations, and processes. Furthermore, special lexicon used by the translator in communication can provide with information and knowledge of phenomena specific to some field of science. The term is a linguistic unit which is presented by its lexical expression that is related to its definition and this point is considered to be important in the communication of special knowledge (Brekke, 1999). Language for special purposes (LSP) is characteristic of the terms, whose expression can be rich by variety of formation. Also, the meaning of the term as a linguistic sign, word, etc., and especially the phraseological units can be percepted and realized as dichotomous as being twofold, opposed, or contradictory. 
Semiotics, the science of the $21{ }^{\text {st }}$ century, is considered as an academic study of signs and codes, etc., exploring the ways of produced meaning in the process of communication in the language of science and technology. Danesi (2007) defines semiotics as "the study of the most critical feature of human consciousness" which provides ample competence to create and use signs i.e. words for fulfilling different functions, such as rendering information, cogitating, retaining knowledge, etc. Barrett (2013) treats semiotics as a broad discipline mostly connected to linguistics whose analysis extends far beyond formal language and encompasses certain communication within sign systems. However, the point is that the new way of communication was based on the nature of the linguistic sign (Saussure, 1983, p. 16). The semantic studies involve the semiotic problem regarding the investigation of the nature of the linguistic sign. Furthermore, the information can be communicated through language in words whereas words are also considered as the signs that can be defined as any sensed real things expressing something different that exists beside, whereas the general characteristics of the word are considered to have the particular form expressed by a certain content (Jakaitiene, 2009, p. 13). Moreover, the word can also be considered as the thought and the sign of an abstract thing. On the other hand, the word occurs to be the closest to a symbol, though it is not always considered as a symbol due to the variety of the expressions of words. The word has its form in regard to its linguistic expression and the content that describes its meaning. In other words, the meaning is understood not as a material, but as an ideal factor and even as peculiar constructs (Jakaitiene, 2009, p. 18). It can be argued that the word by its nature can be determined as a conventional sign whereas the word is considered as a unit of linguistic systems such as lexicon, semantics, and grammar (Jakaitienè, 2009, p. 25).

Furthermore, a term as a word can be translated into another language to carry the same idea, the same meaning and the same content explained similarly. Accordingly, the translated terms can produce indeterminacy, ambiguity of named phenomena, and create variants regarding definite interpretation used in the special language of economics in different languages. The point is that analytic English and synthetic Lithuanian can be susceptible to different ways of the formation of terms, sensitive to the explanation of the meaning, and be influenced by the special language regarding the functional variation of the national language. The problem of the study focuses on the terms and term variants used in the special language of economics in the SL (English) and their translation in the TL (Lithuanian). Therefore, the problem is related to the variants relevant to the expression of the terms that cause dichotomy of formation, and meaning in translation from the one language into the other.

The aim of the paper is to investigate the terms of economics, the variants produced in translation from the SL into the TL.

The following tasks are addressed in the study:

- to present a brief overview of the theory relevant to the topic;

- to substantiate the analysis of the terms in regard to the formation, expression, and meaning through translation, and produced variants approaching to the theoretical, typological, and descriptive analysis.

The research methods are: the analysis of the scientific literature; descriptive method; comparative method; method of oppositions.

Translation can be defined as an activity related to various disciplines, among which are linguistics, communication, semiotics, and others. To a large extent translation is attributed to semiotics, the science of signs systems, processes and functions. Signs that are both linguistic and cultural convey a message, yet they are effective only when their significance 
is known to the receiver. Shastri $(2011$, p. 61) states that translation is an act of conveying a message of $S L$ to $T L$ where a message carries meaning that is not directly rendered to the addressee but has to go through a cultural, historical and social prism. In this context semiotics helps to perceive and clarify this meaning.

Semiotics is claimed to derive from two sources: F. de Saussure (Swiss-French) and C.S. Peirce (Anglo-American). Saussure's theory colligates the basis of formal, structuralist linguistics; Pierce's approach is stated to be an extension of reasoning and logic in natural sciences (Saussure, 1983, Pierce, 1958). Saussure highlights that words get the meaning due to arbitrary nature of a language (Saussure, 1983 in Shastri, 2011, p. 61). Being of ever changing nature, a language is also a volatile phenomenon. Therefore, due to changes in economic, cultural, political spheres, words may acquire new meanings or change the current ones. Those changes become a challenge for a translator since all the aspects of current usage should be taken into account. Another prominent linguist Peirce's approach concentrates on verbal and visual signs. In his opinion, cognition, thought and man are all semiotic in character and essence (Shastri, 2011, p. 62). According to Peirce it is extremely important for the translator to perceive the impact of images (both verbal and visual) in the SL culture and translate them in correspondence with their relevance in the TL culture (ibid.). Peirce's theory of semiotics is equally significant for the translator as the one by Saussure.

It can be affirmed that semiotics forms the basis of translation since all words represent signs. Signs in turn can generate the meaning but similar to images they not always and/or not necessarily have the meaning on their own. For this reason it is possible to state that translation is sign-based as it deals with the rendering of verbal and nonverbal signs systems (Bezuidenhout, p. 2). Gorlée (1994, p. 13) shares this viewpoint pinpointing that a language is a system, a coherent semiotic structure and therefore all texts can be analyzed semiotically. Besides, she highlights that translation as well as semiotics involves some facets of communication construing both messages and signs. Moreover, she asserts (1994) that translation involves the aspects of communication mainly concerning the process of operating messages.

Many linguists argue that translation is both a process and a product but the interest for this specific position is relatively new (Gorlée, 2004, Gambier, Doorslaer, 2010, Hatim, Munday, 2007). This conception implies that the term "translation" involves two definite aspects, where the first one centres on the role of the translator in changing the original text into another language, while the second focuses on the result of the translation performed by the translator (Hatim, Munday, 2007, p. 3). Today, translation activity does not take place in isolation from social and technological environment. Thus, Sütiste and Torop (2007, p. 196) introduce translation semiotics, a discipline that provides the techniques to distinguish and differentiate the degree of sign system translatability. Gorlée, who has developed new concepts in semiotics, moves further exploring semiotranslation (2004, p. 13). She argues that semiotranslational approach, if implemented thoroughly, could totally change the whole traditional translation theory, which is still focused on issues like mental and intuitive activities of the sign and the "invisibility" of the translator, the supposed differences between translatability and untranslatability, equivalence, the function and the role of the translator.

Dichotomy is defined as a division or contrast between two things that are represented as being opposed or entirely different (www.oxforddictionaries.com). Dichotomy of form vs. meaning builds the basis of the traditional concept of translation which means that translation will maintain the same content in a different form, i.e., in a different language (Stankevičienè, Švenčionienè, 2010). However, there are no universal methods to produce a perfect translation. An invariant aspect in translation is considered in the case when the meaning of 
communication message is eliminated and the context is neglected, consequently the $\mathrm{SL}$ is identified only in accordance with the structure of the SL. Successively, TL employs the same concept. As a result, translation is introduced as an opposition of SL and TL rejecting the communication essence (Pym, 1992). This concept is considered to be quite controversial in translation theory, still it defines the character of invariant.

Perception and understanding the precise nature of equivalence and its aspects remains an invidious issue. The concept of equivalence has drawn linguists' attention for over half a century. "A much-used and abused term in Translation Studies (Bassnett, 2014, p. 34), equivalence has caused, and it might still cause ardent debates in the domain of translation. In addition, it has been broadly analysed and thorougly discussed from various points of view by prominent linguists. Equivalence in translation has caused many controversies, since the scholars could not come to the unanimous conclusion on its nature applicability and even its definition. The definition given by dictionary.com describes equivalence as "the state or fact of being equivalent; equality in value, force, significance, etc." (http://dictionary. reference. $\mathrm{com} /$ ). Accordingly, the meaning of two terms is treated as equivalent when characteristic features of both concepts are the same (Kontutyte, 2008).

Being "a central concept in translation theory", yet a "controversial one" (Kenny 2001, p. 77), equivalence has caused to raise a diverse opinions. In the 1960s the most influential equivalence theories started to evolve. Namely, in the 1960s and 1970s equivalence was meant to indicate that ST and TT share some kind of 'sameness' which in turn impelled to develop different kinds of equivalence. (Panou, 2013). Two French scholars, Jean-Paul Vinay and Jean Darbelnet in 1958 presented a comparative analyses of the different translation strategies and procedures used in French and English languages, their study was translated and first published in English in 1995 (Vinay, Darbelnet, 1995). They argue that equivalence is a procedure in which the same situation is emulated as in the original but with the help of different words (Vinay, Darbelnet, 1995, p. 32). Therefore, translators are incited first of all to consider the situation and then to come up with a suitable equivalent. They also suggest having "full equivalents" in bilingual dictionaries when there is a necessity for equivalent expressions between language pairs (Vinay, Darbelnet, 1995, pp. 255-256).

Almost at the same time, a prominent Russian - American linguist Roman Jakobson pinpoints that there can not be full equivalence between two words (Jakobson, 1959/2000, in Hatim, Munday, 2007, p. 114). Moreover, he emphasizes the differences in the structure and terminology of languages. Jakobson also makes a very important distinction between three types of translation, namely intralingual (translation within the same language, which can involve rewording or paraphrasing), interlingual (translation from one language to another) and intersemiotic (translation of the verbal sign by a non-verbal sign) (Jakobson, 1959/2000 in Hatim, Munday, 2007, p. 5). However, Jakobson does not state that translation involves the word-for-word replacement of linguistic items but instead entire messages in another language have to be replaced (Hatim, Munday, 2007, p. 124). In other words, if two languages are compared, first of all their mutual translatability should be taken into account.

Comparing Vinay and Darbelnet's views on equivalence and the ones by Jacobson's, it is possible to make a conclusion that translation can exist despite cultural or grammatical differences between SL and TL (Panou, 2013). They also accept the translator's role allowing him/her to choose the most appropriate procedures of rendering ST message in the TT.

Another prominent scholar Peter Newmark, one of the founders of the Institute of Linguists in his books Approaches to Translation (1981) and A Textbook of Translation (1988) makes attempts to give a basis for dealing with problems occurring during the translation process. 
He proposes two kinds of translation: semantic (focused on meaning) and communicative (centered on effect). Stating in other words, semantic translation tends to retain SL characteristics, whereas communicative translation tries to satisfy the addressees' needs. (Panou, 2013). These two methods of translation may be used simultaneously depending on the type of text to be translated. Despite being subjected to criticism for his prescriptivism (Munday, 2001, p. 46), his books beyond debate provide valuable advice for translators.

One more perspective is presented by an eminent linguist Mona Baker who in her influential book In Other Words (2011) analyzes the problem of equivalence presenting a more neutral standpoint. There she states that equivalence is a relative notion which is influenced by different linguistic and cultural factors $(2011$, p. 6). She also makes a distinction between a word-level and above-word-level equivalence. Furthermore, Baker highlights the importance of individual words during the translation process since the words should be regarded as single units in order to find their equivalent in the TL (2011, pp. 11-12). She also sets the goals for the translator to recreate SL message in the most appropriate and comprehensive way. Baker made a huge contribution to translation studies providing the translators with specific strategies of dealing with a variety of translation issues.

Another scholar Pym (1992, p.37) points out the circularity of equivalence which is supposed to define translation and translation, in turn, is supposed to define equivalence. Later on he defines (2010, p.37) the concept of equivalence where he pinpoints that perfect equivalence between languages does not exist, there can be only assumed equivalence. He argues that equivalence is a connection of "equal value" between SL unit and TL unit which can be set up on any linguistic unit from form to function (2010, p.7 in Panou, 2013).

Finally, Bassnett (2014, p.34) highlights that equivalence in translation ,should not be approached as a search for sameness, since sameness cannot even exist between two TL versions of the same text, let alone between the source language (SL) and the TL version“.

Generally speaking, equivalence expressed by complete identity would be impossible because languages are different and complex linguistic systems and translation takes place not only between languages but also between texts interpolated in complicated communicative context. The translator needs to possess linguistic, communicative and textual competences to fully understand the meaning of a specialised topic.

In addition, non-equivalence or zero equivalence is distinguished signifying that the target language has no direct equivalent for a word or a phrase in the source language or the SL concept is not lexicalized in the TL since the TL culture does not have a word to denote it (Baker, 2011). Moreover, the TL may have a different number of distinctions in meaning than the SL. As a matter of fact, each language is unique and while one language may regard some distinctions in meaning important, another language can despise or treat them as not essential. Differences in form is one more important factor in non-equivalence: certain suffixes and prefixes which convey prepositional and other types of meaning in English often have no direct equivalents in other languages (Baker, 2011, pp.18-19).

All in all, in translation the main point of interest is equivalence, therefore transferring the meaning of the word from the SL to the TL should be as accurate as possible. Gouadec (2007, p. 11) specifies "economic translation", in which the issue of terminological controversies, ambiguities, variants should be carefully concidered and managed. Terminology of different languages is formed according to numerous terms coinage techniques in compliance with certain requirements of wordbuilding principles.

According to a terminology textbook, a term is a word or expression representing the concept of special area (Terminologijos vadovèlis Europos Komisijos vertimo raštu Generealinio 
direktorato Lietuviu kalbos departamento vertejams, 2006). With reference to the structure, terms are simple, or one-word and compound, that is consisting of two, three or more words. However, there are far more compound terms but almost all their basis is composed of simple terms. New coined terms must meet certain requirements. Thus, systematicity and consistency are the key features of the term, since terms, like all words, do not exist in isolation and constitute certain systems with which they should be compatible. Besides, a term must satisfy the language lexical, morphological, derivational, syntactic and phonological rules. At the same time, the inner form of the term has to convey the concept accurately and clearly.

It is noteworthy to mention that term coinage techniques and trends in the Lithuanian language are different from English, French or German. To ensure the clarity and accuracy of terms, it is essential to consult not only with subject experts, who are familiar with the area conceptual framework, but also with the Lithuanian language national experts.

It can be stated that the majority of economics terms are formed according to the dominant terms and their term variants in English. However, newly created term variants are not always applicable to the specific domain of economics, thus causing indeterminacy in that field. Besides, term variants might put linguists in doubt concerning the term relevance.

While creating new terms, it is of underlying importance to avoid ambiguity, synonymy (no new concept term must be coined if there is another suitable term for the same concept), and homonymy. The format of terminology principles and methods has been standardized according to ISO standards. Namely, ISO 704:2009 sets the standards for compiling terminology, characterizes connection between an object and its concept, settles the principles of word formation, designation of the meaning, and determines definitions requirements (IS0 704:2009).

In terminology word building plays a huge role, since an overwhelming majority of both simple terms and compound terms components are derivatives (Keinys, 2005, p. 21). Most of noun derivatives used in terminology are formed with the help of suffixes, for instance, simple terms noun derivatives with suffixes constitute $81 \%$ in economics glossaries. However, terms formed with the help of endings, prefixes and compound terms make up an insignificant minority (ibid.). This fact confirms the great prevalence of noun derivatives with suffixes in the current Lithuanian language. Moreover, new terms can be created out of the existing forms by using conversion, terminological meaning application, change of the meaning and an interdisciplinary borrowing method. It should be taken into consideration that the usage of existing forms may cause homonymy (when two unrelated concepts are identified by the identical terms), and therefore lead to confusion and ambiguity. However, in the development of new forms it may be useful to combine the existing terms (e.g., to create multiword terms, compounds). Besides, new terms can be coined using the method of conversion by changing the grammatical category of the existing forms.

It is necessary to state that borrowing from other languages seems to be the simplest but at the same time the most insidious way of creating terms. This method is defined as the process by which the term is borrowed from one subject area and is assigned to the new concept of the object in a different subject area within the same language (Lubiené, 2013). Terms are quite often borrowed from other languages. A loanword adopted by the language can be pronounced, written or inflected in a different way. However, whether or not a new loanword is acceptable in the official usage is usually determined by Lithuanian State Language Commission that validates borrowings in use exploited by subject matter experts (Terminologijos vadovèlis Europos Komisijos vertimo raštu Generealinio direktorato Lietuviu kalbos departamento vertejams, 2006). It is emphasized by ISO standards that borrowing from other languages is an acceptable way of creating terms, however, priority should be given not to direct borrowing but to expression measures of the native language (LST ISO 704). Thus, ISO 
standards are of great importance, while creating new terms and compiling terminological glossaries with ISO 704:2000 as the most important (Kudashev, 2007).

Besides, huge efforts are put to the issue that one concept should be signified by a single term and one term should have only one meaning. However, during the transitional phase of term development there may be synonymous terms and polysemous terms.

Specifically, some terms may have more than one designation or denotation in addition to the already existing ones which are treated as synonyms or variants. Also, they may be defined or explained in the same way (Stankevičienè, Švenčionienè, 2013). The concept variant is assumed to be the same lexical unit possessing a different form but similar meaning. Variants may be presented as having different characteristics of the meaning or some peculiarities of properties' modifications. ISO terminology standards define synonyms as words having a different stem, whereas variants are words of the same stem, but having different endings, prefixes and suffixes (ISO 10241,1992 in Stankevičienè, Švenčionienè, 2010). However, as Lithuanian terminology has no evident distinction between the concepts of variant and synonym, therefore variants can be considered to be a part of synonymy in a broad sense (Stankevičienè, Švenčionienè, 2010).

The issues of synonymy and variants in terminology have been analyzed from various aspects. First of all, it must be acknowledged that synonyms in the theory of terminology are considered to be a big flaw, an unnecessary and harmful phenomenon (Keinys, 2005, p. 254). Moreover, both in terminology literature and the introduction of the standards it is unanimously stated that both synonymy and variants of terms and their components has to be unambiguously eliminated. However, D. Lotte (Lottè, 1961 in Keinys, 2005, p. 254) proposes some cases when the usage of term synonyms and variants can be justified. The first case defines the aspect when in various term systems it is necessary to characterize different properties of the same concept. The second one occurs when one of the two used terms is a shorter variant. In all other cases, using terms synonyms and variants is unacceptable. However, in practice and even in standard sets it is quite widespread.

To sum up, the major task for linguists terminologists is to offer term variants that are applicable to the Lithuanian language formation principles and fit the existing terminology system. Specifically, considering the economic context with rapidly growing networking between countries, it has become especially important to find effective ways both to translate and create economic terms avoiding ambiguity. Translation and creation of economic terms requires deep knowledge of the subject matter, linguistic expertise, in other words it requires consistency, mutual interaction between a translator and the economics expert. Tagkas (2014) states that although translation techniques and conversance of translation theories provide a necessary methodology for translators, "there can be no translation without understanding of meaning". Every special lexicon, including economics, requires uniform and comprehensible terms equivalents in the TL.

The corpus for the analysis is mainly based on The Explanatory English-Lithuanian Dictionary of Economics, and on online dictionaries to a minor extent: http://dictionary. reference. com/, http://www.thefreedictionary.com/, http://www.investopedia.com/, http:// www. dictionarycentral.com/. The study is carried out as an analysis combining both descriptive and comparative approaches. The analysis focuses on investigating ambiguity of the meaning, extended meaning of the special lexicon, differentiating lexical variants, exploring the terms of economics in regard to equivalence in translation focused on expression and meaning. 
The dichotomy of the translational expression and meaning. The term can be understood as a unit of special language, consisting of some spoken sounds and written sound representation that presents a principal meaning. When used in a language, the forms as lexical units are separated from other units by spaces, and in some cases, by a hyphen in writing, and also the term is distinguished phonologically, as by accent or pause that specialists in the field of economics can identify. Furthermore, when the term is translated into the TL, its form is rendered to the different string of phonemes and its expression can be understood as the same meaning having the same content, and described in the same way. The first group of the examples comprises the terms in the SL (English) that cover the translation equivalents into the TL (Lithuanian).

(a) The examples contain a single expression of the term composed of a one-word unit in the $S L$ that coincide for the single expression of a one-word unit in the $T L$, e.g.:

Eng. production // Lith. gamyba (AEA-LKŽ 2006, p. 507); Eng. firm // Lith. imone (AEA-LKŽ 2006, p. 235); Eng. sample // Lith. imtis (AEA-LKŽ 2006, p. 558); Eng. exchange // Lith. mainai (AEA-LKŽ 2006, p. 213); Eng. hoarding // Lith. kaupimas (AEA-LKŽ 2006, p. 280).

(b) The investigated examples are comprised of a single expression of the term composed of a one-word unit in the SL that can be equivalent to the expression of a two-word unit in the TL, e.g.:

Eng. detrending // Lith. nuonešio pašalinimas (AEA-LKŽ, 2006, p. 162); Eng. outlier // Lith. išsiskiriantysis stebinys (AEA-LKŽ, 2006, p. 466); Eng. absenteeism // Lith. nebuvimas darbe (AEA-LKŽ, 2006, p. 14); Eng. securities // Lith. vertybiniai popieriai (AEA-LKŽ, 2006, p. 564).

(c) The examples contain a single expression of the term composed of a one-word unit in the $S L$ that can be equivalent to the expression covering a three-word unit in the $T L$, e.g.:

Eng. maturity // Lith. obligaciju išpirkimo data (AEA-LKŽ 2006, p. 402); Eng. flotation // Lith. viešoji akciju emisija AEA-LKŽ 2006, p. 241); Eng. specie // Lith. tauriuju metaly monetos (AEA-LKŽ 2006, p. 585).

(d) The examples contain a single expression of the term composed of a one-word unit in the $S L$ that can be equivalent to the translated expression of a four-word unit in the TL, e.g.:

Eng. royalty // Lith. gamtos ištekliu gavybos mokestis (AEA-LKŽ, 2006, p. 555); Eng. sackings // Lith. atleidimai dèl darbuotojo kaltés (AEA-LKŽ, 2006, p. 557).

(e) The analysed examples of the terms present the compounds expressed by a one-word unit in the SL, though the translated terms can cover the expressions comprising the different number of words in the TL, i.e. one-word, two-word, and three-word units.

- the compounds of the type noun stem+noun stem, e.g.: Eng. guideposts // Lith. gaires (AEA-LKŽ, 2006, p. 271); Eng. goodwill // Lith. prestižas (AEA-LKŽ, 2006, p. 263); Eng. piecework // Lith. atlyginimas pagal išdirbi (AEA-LK, Ž 2006, p. 484); Eng. overpopulation // Lith. gyventoju perteklius (AEA-LKŽ, 2006, p. 467);

_ $\quad$ the compounds of the type adjective stem+noun stem, e.g.: Eng. flexitime // Lith. slankusis darbo laikas (AEA-LK,Ž 2006, p. 240); Eng. overfunding // Lith. perviršinis finansavimas (AEA-LKŽ, 2006, p. 467).

(f) Next, the term can comprise a phrase that covers the expression of a sequence of two or more words arranged in a grammatical unit lacking a finite verb. The translation of the investigated examples of the terms as the phrases in the SL can correspond to the same structure of the phrase in the TL, e.g.:

Eng. pattern bargaining // Lith. modelinés derybos (AEA-LKŽ, 2006, p. 475); Eng. tax shifting // Lith. mokesčiu perkèlimas AEA-LKŽ, 2006, p. 613); Eng. price taker// Lith. kainu gavejas (AEALKŽ, 2006, p. 502); Eng. overnight money // Lith. nakties paskolos (AEA-LKŽ, 2006, p. 467). 
(g) The analysed examples of the phrasal expression comprising two-words in the SL can correspond to the expression composed of three- or four-words in the TL, e.g.:

Eng. salvage value // Lith. galutine liekamoji verte (AEA-LKŽ, 2006, p. 557); Eng. stock market // Lith. vertybiniu popieriu rinka (AEA-LK,Ž 2006, p. 597); Eng. strike insurance // Lith. streiko nuostoliu drauda (AEA-LKŽ, 2006, p. 599); Eng. stock option // Lith. vertybiniu popieriu pasirinkimo sandoris (AEA-LKŽ, 2006, p. 597).

(h) Next, the phrase expressed by three-words in the SL can correspond to the expression of a different number of words making the phrase of one-, two-, three-, and four-words and / or even can satisfy the phrase comprising six-words in the TL, e.g.:

Eng. wear and tear // Lith. nusidevejjimas (AEA-LKŽ, 2006, p. 666); Eng. working capital ratio // Lith. apyvartinio kapitalo santykis (AEA-LKŽ, 2006 p. 674); Eng. weighted least squares // Lith. svertinis mažiausiuju kvadratu metodas (AEA-LKŽ, 2006, p. 667); Eng. price specie mechanism // Lith. kainu ir tauriuju metaly monetu mechanizmas (AEA-LKŽ, 2006, p. 502).

(i) The investigated examples of the terms in the SL can have the expressions of two- or three-words that are joined by a hyphen, whereas the translated expressions of the terms can correspond to the expression of a different number of words without hyphen in the TL, e.g.:

Eng. take-off // Lith. kilimas (AEA-LKŽ, 2006, p. 608); Eng. well-behaved // Lith. "geros" elgsenos savybe (AEA-LKŽ, 2006, p. 668); Eng. grant-in-aid // Lith. pagalbinis garantas, dotacija (AEA-LKŽ, 2006, p. 265). Eng. paid-up capital / Lith. apmoketasis kapitalas (AEA-LKZ̆, 2006, p. 469); Eng. Taft-Hartley Act / Lith. Tafto ir Hartley istatymas (AEA-LKŽ, 2006, p. 608).

Summing up, the investigated examples of the terms in the $S L$ and their translation in the TL highlight the variety of the different expressions of composition: a single expression in the $\mathrm{SL}$ (English) for a single expression in the TL, though many cases of the analysed examples cover the differences that do not conform with the forms and expressions regarding the two-, three-, or more words that make up the term.

The binary aspect / dichotomy of the transliteration and transcribed forms. When the $\angle$ term is translated, the characters of the alphabetic writing system of the SL are represented by the characters from the alphabetic writing of the TL. Also, the pronunciation of the converted characters is taken into account. The second group of the examples cover scientific terms (nominals) that are typically constructed from classical roots, stems and derivational morphemes (Greek or Latin) to form the composite expressions.

(a) The analysed examples contain the terms of the SL that cover the transcribed expressions in the TL, e.g.:

Eng. antilogarithm // Lith. antilogaritmas (AEA-LKŽ, 2006, p. 36); Eng. mercantilism // Lith. merkantilizmas (AEA-LKŽ, 2006, p. 406); Eng. monetarism // Lith. monetarizmas (AEALKŽ, 2006, p. 414), Eng. maximin // Lith. maksiminas; Eng. maximax // Lith. maksimumas; Eng. maximum // Lith. maksimumas (AEA-LKŽ, 2006, p. 37), Eng. super-neutrality // Lith. superneutralumas (AEA-LKŽ, 2006, p. 603), etc.

Furthermore, the expression of the analysed example of the term as well as its transcribed form is highlighted by the international root, e.g.: Eng. autarky // Lith. autarkija (AEA-LKŽ, 2006, p. 43). However, most often the meaning of the term is vague and it needs to be explained in English by the definition, e.g., Eng. autarky is considered to be an economic independence as a national policy (http://www.thefreedictionary.com/). However, the definition of the term can be considered as a different variant of the meaning.

(b) The analysed examples of the terms cover the transcribed forms of the SL that are presented in the TL, e.g.: 
Eng. grant // Lith. grantas (AEA-LKŽ 2006, p. 265); Eng. acceptance // Lith. akceptavimas (AEA-LKŽ, 2006, p. 16); Eng. discounting // Lith. diskontavimas (AEA-LKŽ, 2006, p. 168), etc.

(c) Peculiar examples of the terms are found in academic texts regarding the transcribed expressions, the case that special dictionaries in Lithuanian do not enlist the translingual borrowing, e.g.:

Lith. ... nacionalinio produkto deviaciju priežastis gali būti... (Jakutis et al., 1999). Lith. .. dvi prekés yra substitutai (pakeicia viena kita) ar komplementarios (vartojamos kartu) (Jakutis et al., 1999). Whereas the analysed dictionary presents the single expression of the term in the $\mathrm{SL}$ being equivalent to the single expression in the $\mathrm{TL}$, e.g.: Eng. deviation // Lith. nuokrypis (AEA-LKŽ, 2006, p. 163); Eng. substitute // pakaitalas (AEA-LKŽ 2006,

p. 601); Eng. complements // Lith. papildiniai (AEA-LKŽ, 2006, p. 117).

Thus, the investigated examples of the terms in the $S L$ and the transcribed expressions regarding the terms in the TL highlight the variety of different variants that have translation equivalents as: transliterated variants of the translingual borrowings and / or of Lithuanian origin. However, the meaning of the terms of the international origin usually is not perceived and they need additional explanation or definition.

3 The variants / dichotomy of translational and transcribed expressions. The third 3 group is composed of the translated examples that cover the terms having two expressions: one of the TL (i.e. national origin) whereas another transcribed expression of the term is considered as an international borrowing, and it can be regarded as a variant of the different formation.

(a) One lexical unit in the SL (English) can be equivalent to a different formation of two lexical units in the TL (Lithuanian), i.e. one-to-two equivalence. The preference is given to the expressions of the national origin, whereas the transcribed expressions are presented as variants. Though the cases of the mixed formation can also occur, e.g.:

Eng. accelerator // Lith. greitiklis, akceleratorius (AEA-LKZ̆, 2006, p. 16); Eng. conversion // Lith. (pa) keitimas, konversija (AEA-LKŽ, 2006, p. 127); Eng. convertability // Lith. pakeičiamumas, konvertuojamumas (AEA-LKŽ, 2006, p. 127), etc. Eng. deficit//Lith. deficitas / lèšu stoka AEA-LKŽ, 2006, p. 154); Eng. autocorrelation // Lith. autokoreliacija / eilutine koreliacija (AEA-LKŽ, 2006, p. 43), etc.

(b) The expression of the compound term is considered as one unit though the term can be expressed by the different number of words: (1) the first expression of the term represents a two-word unit of the national origin, and (2) the second expression of the term is of a mixed origin, i.e. of the transcribed and of the national origin, and vice versa, e.g.:

Eng. adaptive expectations // Lith. suderintieji lūkesčiai / adaptyvieji lūkesčiai (AEA-LKŽ, 2006, p. 19); Eng. clearing house // kliringo rūmai / iskaitos rūmai (AEA-LKŽ, 2006, p. 102), etc.

(c) The examples of compound term composed of a three-words unit used with the hyphen in the SL whereas the translated expressions of the terms present the formation without any hyphen and can be comprised of a mixed origin, and / or bear the transcribed form, e.g.:

Eng. grant-in-aid // Lith. pagalbinis grantas / dotacija (AEA-LKŽ, 2006 p. 256); Eng. balancedbudget multiplier // Lith. subalansuotojo biudžeto daugiklis / subalansuotojo biudžeto multiplikatorius (AEA-LKŽ, 2006, p. 50). Eng. capital-labour ratio // Lith. kapitalo ir darbo santykis (AEA-LKŽ, 2006, p. 88);

(d) The special case of the analysed examples is a group of terms that reflects the origin of Latin and French languages. Such terms can be used as internationalisms with the same identical phonemic expression in the TL. The pronunciation rules are observed for the words 
of French origin. Also the international expressions regarding to the terms of Latin and French origin can be translated into the TL (Lithuanian), e.g.:

Lat. a priori // Eng. conceived beforehand // Lith. iš anksto (AEA-LKŽ, 2006 p. 37); Lat. ceteris paribus // Eng. with all other factors or things remaining the same // Lith. kitoms sqlygoms nepakitus (AEA-LKŽ, 2006, p. 97); Lat.. ad valorem tax // Eng. value-added tax, vat // Lith. vertes mokestis (AEA-LKŽ, 2006, p. 22), etc.

Fr. tâtonnement // Eng. a perfect equilibrium is reached // Lith. artutinis (pusiausvyros kainu) nustatymas (AEA-LKŽ, 2006, p. 610); Fr. laissez faire / Eng. literally, allow to act // Lith. leiskite veikti (AEA-LKŽ, 2006, p. 353); Fr. numéraire / Eng. a unit of account // Lith. apskaitos matas (AEA-LKŽ, 2006, p. 454), etc.

To sum up, the analysed characteristics of the meanings of the compared examples display a variety of information indicating the sameness, similarity, or interchangeable properties that coincide with the general and paraphrased meaning of the term, and the differences that do not conform with the general meaning in regard to the specificity of the term in the dictionaries in one or the other compared language. The third group is composed of the examples regarding the terms that contain one lexical unit in the $S L$ being equivalent to two lexical units in the TL variant.

The binary aspect / dichotomy regarding to initialisms and capitalisation. The fourth group of the analysed examples contains abbreviated forms of the terms that consist of some initial letters of words and thus make up a multiword term whereas the term elements make up a compound term when these letters are pronounced individually.

(a) The phonological and orthographic sound or expression of the initial letter can be used to describe or identify something, i.e. an organization, company, product, or process, etc., e.g.:

Eng. Government National Mortage Association (GNMA) // Vyriausybès nacionaline hipotekos asociacija (AEA-LKĽ, 2006, p. 263); Eng. CBI Confederation of British Industry // Brity Pramonés Konfederacija (AEA-LKŽ, 2006, p. 94); Eng. USM Unlisted Securities Market // Ne Biržos Sąrašo Vertybiniu Popieriu Rinka (AEA-LKŽ, 2006, p. 645); Eng. COLA cost of living // pragyvenimo išlaidu suderinimas (AEA-LKŽ, 2006, p. 106); Eng. value-added tax (VAT) // pridètinés vertés mokestis (PVM) (AEA-LKŽ, 2006, p. 647); Eng. PRT petroleum revenue tax // Naftos gavybos mokestis (AEA-LKŽ, 2006, p. 514), etc.

(b) A specific example of the expression in regard to the word pattern used with the initial sign / or symbol is described, in which the initial element is a sign expressed by a letter that is followed by the complete words, e.g.:

Eng. U-form enterprise / U-form and M-form organizations are compared // Lith. U-imone (AEA-LKŽ 2006, p. 635); Eng. U-shaped cost curves / Eng. the term defines the average cost per unit that begins high and drops as production increases, so the cost curve looks like the letter U (http://www.investopedia.com/) // Lith. U pavidalo kaštu kreivès (AEA-LKŽ, 2006, p. 645), etc.

Eng. t-distribution / Eng. a type of probability distribution is theoretical and resembles a normal distribution (http://www.investopedia.com/) // Lith. t-skirstinys (AEA-LKŽ, 2006, p. 613).

Eng. X-efficiency / Eng. the degree of efficiency is maintained by individuals and firms under conditions of imperfect competition (http://www.investopedia.com/) // Lith. X-veiksmingumas (AEA-LKŽ, 2006, p. 676).

(c) The expression of the example of the term is composed of the capital letter which is followed by number, e.g.:

Eng. G7 / a forum of the world's seven most industrialized economies (http://www.investopedia. com/) // Lith. didysis septynetas (AEA-LKŽ, 2006, p. 271). 
(d) Special cases of the analysed examples in regard to the expressions of the terms are used with the initial non-capitalised letter, e.g.:

Eng. bancor / hypothetical supranational currency // bankoras (AEA-LKŽ, 2006, p. 52); Eng. boulwarism / a form of labor-management negotiation // Lith. bulverizmas (AEA-LKŽ, 2006, p. 74).

Whereas the on-line dictionary presents the terms expressed with the initial capital letter, however with a change in meaning, e.g.:

Eng. Bancor / refers to the People's Bank of China (http:// www. dictionarycentral.com/); Eng. Boulwarism / a strategy named after Lemuel Boulware (http://www.thefreedictionary.com/).

(e) The surnames of researchers can be used in the formation of the compound terms. Some of the analysed examples cover the surnames of the authors and initiators of some invented methods, theorems, and laws in the specialised field of science. Therefore, such terms are used with the initial capitalised letter. The system of the Lithuanian alphabet does not comprise such symbols of letters as ' $W$ ', ' $Q$ ', ' $X$ ', ' $Y$ ', etc. However, the presented expression covers the writing system of system in English, e.g.:

Eng. Wharton model // Whartono modelis (AEA-LKŽ, 2006, p. 666). Eng. Ramsey pricing // Lith. Ramsey kainodara (AEA-LKŽ, 2006, p. 527);

(f) However, the presented expressions of the examples bear the marking rules to indicate the relationship between the things and objects, or to designate more than one object, etc. within the phrase of the English and Lithuanian language, e.g.:

Eng. White plan // Lith. White'o planas (AEA-LKŽ, 2006, p. 669). Eng. Bayesian techniques // Bayeso metodai (AEA-LKŽ, 2006, p. 63); Wagner's law // Lith. Wagnerio desnis (AEA-LKŽ, 2006, p. 663); Eng. Weberian location theory // Lith. Weberio teritorinio išsidéstymo teorija (AEA-LKŽ, 2006, p. 666).

The following examples mark the grammatical case related to the marking system in English, whereas the presented word with the marked ending in Lithuanian indicates the relationship within the phrase (i.e. grammatical case, gender, and number). The term can be expressed by the initial letters or syllables taken from a group of words and can form the name known as initialisms or sometimes called alphabetisms, that are formed from the initial letters of a string of words and are pronounced as a sequence of letters. The dictionaries in English present the expression of the terms that differ in orthography.

5 The binary aspect / dichotomy of form relevant to the meaning. The fifth group com5 prises examples in regard of dichotomy of form relevant to the meaning.

(a) The following example represents the case when one term designation in Lithuanian is given two translation variants in English.

Eng. satiation // sotis (AEA-LKŽ, 2006, p. 559); Eng. saturation // sotis (ibid);

(b) The same expression in English which has an additional or different meaning in Lithuanian.

Eng. securitization // Lith. blogu paskolu pardavimas (AEA-LKŽ, 2006, p. 565); Eng. securitization // Lith. skoly vertybiniu popieriu emisija (AEA-LKŽ, 2006, p. 565);

Eng. stock // Lith. vertybiniu popieriu kapitalas; vertybiniai popieriai; sankaupa (AEA$L K \check{Z}, 2006$, p. 565);

Thus, the analyzed characteristics of the meanings of the compared examples display the variety of information indicating the sameness, similarity, or interchangeable properties that coincide with the general and paraphrased meaning of the term, and the differences that do not conform with the general meaning in regard to the specificity of the term in the dictionaries in the one or the other compared language.

(The examples are taken from dr., assoc. prof. D. Švenčionienè's data). 


\section{Conclusion}

\section{References}

1. Baker, M., 2011. In Other Words-A Coursebook on Translation. Second edition. Paris \& New York: Routledge.

2. Barrett, R., 2013. Semiotics: Putting Theory into Practice. Lexi@, Undergraduate Journal in Writing, Rhetoric\& Technical Communication, Volume 1, Spring. [Online] available at: http:// www.jmu.edu/lexia/volume_1/Semiotics. html [accessed February 2015].

3. Bassnett, S., 2014. Translation Studies. 4th rev. edn. London, Routledge.

4. Bezuidenhout, I., n.d. A Discursive -Semiotic Approach to Translating Cultural Aspects in Persuasive Advertisement. [Online] available at: http://ilze. org/semio/017.htm [accessed January 2015].

5. Brekke, M., 1999. Popular vs. Professional Aspects of Economics Texts in English. Hermes, Journal of Linguistics no. 23. [Online] available at: http://download2.hermes.asb. dk/archive/FreeH/H23_03.pdf [accessed February 2015].

6. Danesi, M., 2007. The Quest for Meaning: A Guide to Semiotic Theory and Practice. University of Toronto Press

7. Gambier, Y., Doorslaer, L., van, 2010. Handbook of Translation Studies. Volume 1. (Ed.) John Benjamins Publishing.

8. Gorlée, D. L., 2004. On Translating Signs: Exploring Text and Semio-Translation (=Approaches to Translation Studies, 24). Amsterdam and New York, NY: Rodopi.
9. Gorlée, D. L., 1994. Semiotics and the Problem of Translation: With Special Reference the Semiotics of Charles S. Peirce. Amsterdam, Rodopi.

10. Gouadec, D., 2007. Translation as a Profession. Amsterdam, John Benjamins Publishing Co.

11. Hatim, B., Munday, J., 2007. Translation-An Advanced Resource Book. Routledge.

12. ISO 704: 2000(E). Terminology Work Principles and Methods. Geneve: ISO. [Online] available at: http://semanticweb.kaist.ac.kr/ org/tc37/pdocument/standards/ISO\%20704. pdf [accessed January 2015].

13. ISO 704:2009. Terminology Work. Principles and Methods. [Online] available at: http:// www.iso.org/iso/iso_catalogue/catalogue_ tc/catalogue_detail.htm?csnumber=38109 [accessed January 2015].

14. ISO 10241:1992(E) International Terminology Standards - preparation and layout.

15. Jacobson, R., 1959/2000. On linguistics aspects of translation. In Venuti, L. (ed.), 2000, The Translation Studies Reader. London and New York: Routledge, pp. 113-118.

16. Jakaitienè, E., 2009. Leksikologija: studiju knyga. Vilniaus Universiteto Leidykla.

17. Jakutis, A., Petraškevičius, V., Stepanovas, A., Šečkutè, L., Zaicev, S., 1999. Ekonomikos teorijos pagrindai : vadovélis aukštuju mokyklu studentams. Vilniaus Gedimino technikos universitetas. Kaunas:Smaltija. 
18. Keinys, S., 2005. Dabartiné lietuviu terminologija. Lietuvių kalbos institutas, Vilnius.

19. Kenny, D., 2001. Equivalence. In M. Baker, ed. Routledge Encyclopedia of Translation Studies, London, Routledge, pp. 77-80.

20. Kontutytè, E., 2008. Imonių teisinès formos: vokišku ir lietuviškų terminu ekvivalentiškumo problemos. In Kalbotyra, 58 (3), pp.69-79

21. Kudashev, I., 2007. Terminography vs. Lexicography: Opposition Revisited. VAKKI, Nr 34. Vasa, pp.157-166. [Online] available at: http://www.vakki.net/publications/2007/ VAKKI2007_Kudashev.pdf [accessed January 2015].

22. Lotte, D. S., 1961. Osnovy postroenija naucnotechniceskoj terminologii. Moskva. [Online] available at: lotte_1961osnovy_postroenija_ nt_terminologii.pdf [accessed March 2015].

23. Lubienè, J., 2013.Terminologijos paskaity konspektas. Metodinè priemonè aukštuju mokyklų studentams. Klaipèda.

24. Munday, J., 2001. Introducing Translation Studies. Paris \& New York: Routledge

25. Newmark, P., 1981. Approaches to Translation. Oxford and New York: Pergamon Press.

26. Newmark, P., 1988. A Textbook of Translation. New York: Prentice Hall.

27. Panou, D., 2013. Equivalence in Translation Theories: A Critical Evaluation. Theory and Practice in Language Studies, vol. 3, no. 1, pp.1-6, January. [Online] available at: http:// ojs.academypublisher.com/index.php/tpls/ article/view/tpls03010106/6188 [accessed February 2015].

28. Peirce, C. S., 1958. Selected Writings. Piener (Ed.), New York: Dover Press.

29. Pym, A., 2010. Exploring Translation Theories. London \& New York: Routledge.

30. Pym, A., 1992. Translation and Text Transfer. Frankfurt, Peter Lang.

31. Saussure, F. de, 1983. Course in General Linguistics, London: Duckwort.

32. Shastri, P. D., 2011. Fundamental Aspects of Translation. PHI Learning Pvt. Ltd.

33. Stankevičienè, V., Švenčionienè, D., 2013. The Comparative Analysis of the Semantic Group of the Term "Money" in the Dictionaries of Economics. Changes in Social and Business Environment: Proceedings of the $5^{\text {th }}$ International Conference. KTU Panevežys Institute.

34. Stankevičienè, V., Švenčionienè, D. (2010). Terminology: the Term Variance in the English and Lithuanian Special Language of Economics. Nation and Language: Modern Aspects of Socio-linguistic Development: Proceedings of the 4th International Conference, Panevežys, Lithuania/ Kaunas: Technologija, pp. 97-101.

35. Sütiste, E., Torop, P., 2007. Processual Boundaries of Translation: Semiotics and Translation Studies. In Semiotica 163 - 1/4, Walter de Gruyter, pp.187-207.

36. Terminologijos vadovélis: Europos Komisijos vertimo raštu Generalinio direktorato Lietuviu kalbos departamento vertejams. 2006. Liuksemburgas. [Online] available at: http://ec.europa. eu/translation/lithuanian/guidelines/ documents/terminology_guidelines_lt.pdf [accessed January 2015].

37. Tagkas, P., 2014. Translation of Economic Texts: Challenges and Limitations. In Arslan, F., ed. Contemporary Issues on Linguistics and Language: LILA '14/Linguistics and Language Conference Proceedings. Istanbul: DAKAM Publishing. pp. 279-287. [Online] available at: http://www.academia.edu/7449883/_ Translation_of_economic_texts_challenges_ and_limitations_Periklis_Tagkas_LILA_14_ [accessed March 2015].

38. Vinay, J.P. and Darbelnet, J., 1995. Comparative Stylistics of French and English: a Methodology for Translation trans. by Sager, J. C. and Hamel, M. J., Amsterdam/Philadelphia, John Benjamins.

\section{Sources:}

1. AEA-LKŽ, 2006. Pearce, D., Aiškinamasis ekonomikos anglu-lietuviu kalbu žodynas. Vilnius: TEV

2. http://dictionary.reference.com/

3. http://www.thefreedictionary.com/

4. http://www.investopedia.com/

5. http:// www.dictionarycentral.com/

6. http://www.oxforddictionaries.com/ 


\section{Santrauka}

\section{Viorika Šestakova. Ekvivalentiškumo siekis verčiant terminų variantais - dichotomijos priežastis}

Tam tikra specializuoto leksikono dalis turi papildomus du ar tris pavadinimus, kurie apima profesini arba vietos naudojimą, ir tokiu būdu gali turèti jtakos kai kuriu variantu atsiradimui originalo ir vertimo kalbose. Kadangi vertimas yra traktuojamas kaip semiotine praktika, tais atvejais, kai termino kaip savybès arba funkcijos požymio reikšme išlieka nepakitusi po tam tikru transformaciju, jis laikomas invariantu. Specializuoto leksikono, ypač variantu vertimas gali reikšti formos ir reikšmès dichotomiją, polinki nukrypti nuo esmès arba paslèpti reikšmiu skirtumą vertimo kalboje. Siekiant leksinių vienetu vertimo ekvivalentiškumo, variantu vartojimas gali sukelti dviprasmybiu, tada žodžio reikšmę vertime galima suprasti kaip interpretaciju grandinę. Tyrimas nagrinejja specializuotą ekonomikos leksikoną naudojant aprašomaji-lyginamaji metodą, susietą su žodžio formos vertimo ekvivalentiškumu ir reikšme originalo ir ne originalo kalbose.

\section{About the Viorika Šestakova \\ author Lecturer in EAP and ESP at Kaunas University of Technology, Faculty of Social Sciences, Arts and Humanities, Lithuania.}

\section{Research interests}

Linguistics, semiotics, ESP.

\section{Address}

Faculty of Social Sciences, Arts and Humanities, Kaunas University of Technology, A. Mickevičiaus Str.37, LT-44244 Kaunas, Lithuania.

\section{E-mail:}

viorika.sestakova@ktu.lt 